\title{
University Students' Perception toward Global Citizenship's Knowledge, Skills and Values in the Sultanate of Oman
}

\author{
Wajeha Thabit Al-Ani ${ }^{1}$ \\ ${ }^{1}$ College of Education, Sultan Qaboos University, Al Khoud, P.O. Box: 32 Postal Code: 123, Muscat, Sultanate of \\ Oman \\ Correspondence: Wajeha Thabit Al-Ani, College of Education, Sultan Qaboos University, Al Khoud, P.O. Box: 32 \\ Postal Code: 123, Muscat, Sultanate of Oman.
}

Received: October 2, 2021

Accepted: November 9, 2021

Online Published: November 11, 2021

doi:10.5430/ijhe.v11n3p40

URL: https://doi.org/10.5430/ijhe.v11n3p40

\begin{abstract}
Global citizenship refers to a sense of belonging to a larger culture and humanity in general. It emphasizes the people's political, economical, social, and cultural interdependence and interconnection at the local, national, and global levels. This study explores university students' perceptions toward global citizenship knowledge, skills, and values in the Sultanate of Oman. To achieve this objective, a descriptive approach was followed by developing a questionnaire including 47 items covering three major dimensions of global citizenship education, namely cognitive, socio-emotional, and behavioral $(\mathrm{CSeB})$. The questionnaire was tested to ensure its validity and reliability and applied to a study sample of 299 students (122 males and 177 females). The findings show statistically significant differences at $(\alpha=0.05)$ between the mean of students' responses who studied Global Citizenship Course (GCC) and those who did not. This reflects the effectiveness of the GCC on students' points of view. Also, the findings show a significant difference between students' points of view regarding the accommodation variable in the cognitive domain in favor of students who live with their families compared with those who live on-campus. GCC plays a significant role in developing student skills and pro-social behavior. The effort to establish a concept of global citizenship is a small step towards a better understanding of its impact and effect.
\end{abstract}

Keywords: student perceptions, global citizenship, values, skills knowledge, Oman

\section{Introduction}

Global citizenship education has become a catchphrase that national educational organizations and scholars have used over the past few years to delineate the emerging internationalization of education. It has emerged as a response to the growing globalization and excessive values of citizenship (Pais, 2020). Whether motivated particularly by worries of disengagement of young people with political systems, like England and Wales, or concerns about social cohesion in multicultural societies, such as the commitment of South Africa to nation-building, citizenship, education has risen as a curricular concern in its own right or as a measurement of the broader curriculum of schools (Hayden, McIntosh, Sandoval-Hernández, Thompson, 2020); Paludan and Prinds, 1999).

According to United Nations Educational, Scientific and Cultural Organization (UNESCO), the key concepts related to global citizenship are awareness, participation, responsibility, cross-cultural empathy, personal achievement, and international mobility (Schattle, 2009). Global citizens need to develop intercultural competence, be knowledgeable and informed of the world and its problems, communicate in different languages, and identify cultural differences.

\subsection{Global Citizenship Definition}

In recent years, academics, educators, and teachers have focused much interest on the concept of citizenship. In 2005, Noddings stated that there was no consensus about the importance of global citizenship, and we cannot use the common term derived from citizenship because global citizenship was not always a matter of allegiance to a non-existent relevant government. For him, a global citizen who was sponsored through a worldwide way of life is someone who can live and work efficiently anywhere in the world (Noddings, 2005). In the same year, McIntosh linked the idea of a global citizen to the behavior of the mind, heart, body, and soul that ought to do with operating for and maintaining a community of ties and interactions across traces of difference and distinction while preserving and strengthening a sense of one's own identity and integrity (McIntosh, 2005). 
Throughout 2017, Hunt predicted that global citizenship education would be transformative, creating awareness, values, and attitudes that learners need to contribute to a more sustainable, legal, and peaceful world (Hunt, 2017). Also, Karlberg said that global citizenship affords a new way of thinking and communicating about our everyday relationships with others, about our situation in the world, our shared values, and, above all, our identities (Karlberg, 2008). Five years later, Carter claimed that global citizenship was viewed as a "product" of globalization, firmly attached to the universal concept (Carter, 2013).

In 1950, Marshall assumed that citizenship is a status especially related to the nation-state, which confers civil, political, and social rights. Civil rights include the rights to personal freedom, freedom of speech, association, religious tolerance, and freedom from censorship under the law. Political reasons include the right to participate in political processes, and social rights include the right to access social benefits and resources, such as education, economic security, and state welfare services. In culturally diverse societies, the primary question related to citizenship is whether separate schooling for religious minorities improves or destroys social cohesion, said Jackson in 2003.

The concept of global citizenship has different meanings. It can mean a sense of belonging to a broader community, beyond national boundaries, which emphasizes common humanity and draws on the interconnection between peoples (UNESCO, 2016). Global citizenship refers to a sense of belonging to a larger culture and humanity in general. It emphasizes the people's political, economical, social, and cultural interdependence and interconnection at the local, national, and global levels (UNESCO, 2014). One of the most famous definitions of global citizenship, which was repeated in various scholarly publications, came from Oxfam in 2006. Oxfam (2006) views a global citizen as someone who:

- is aware of the wider world and has a sense of their own role as a world citizen;

- respects and values diversity;

- has an understanding of how the world works;

- is outraged by social injustice;

- participates in the community at a range of levels, from the local to the global;

- is willing to act to make the world a more equitable and sustainable place, and

- takes responsibility for their actions (p. 3).

\subsection{Related Work}

In 2006, Davies explored whether the perception of global citizenship was too abstract for students to have value in driving curriculum policy and active citizenship by examining three critical elements of an active role: a social justice concern; rights; and cultural conflict. He confirmed the importance of global citizenship, claiming that it could be transformed into a higher radical and politicized curriculum area. He suggested, however, that more significant studies were required on the learning effect, including research by the students themselves (Davies, 2006). One year later, Shultz tested the variation in approaches to global education and global citizenship education. In a globalized neoliberal policy touch, a review of the literature established the connections between citizenship and globalization, as well as the competing discussions and ideologies that surround citizenship education. He concluded that education for global citizenship is a complicated and contested concept and that the implications of their work have to be clear to educators who call for educating global citizenship (Shultz, 2007).

Larsen and Faden's (2008) study was part of a broader project to create and monitor a teaching kit for global citizenship education. Their research focused on evaluating a community of teachers' expectations, attitudes, and beliefs about being globally educated people by asking whether providing teachers with tools for global citizenship education and assisting them in implementing those tools will improve their capacity to be successful global educators. They concluded that global citizenship education teachers are attracted by the norms of social studies (Larsen and Faden, 2008).

In many countries, research on global citizenship is becoming an essential component of citizenship education. However, teachers in the United States are much less interested in linking global viewpoints on citizenship into their teaching. Rapoport explained the barriers preventing social studies teachers from utilizing observations of global citizenship and investigated whether United States performance standards in social studies provide sufficient curriculum guidelines for educating global citizenship (Rapoport, 2009). Rapoport 2009 found that lack of curricular justification and support discourage teachers in the United State from including elements of global citizenship education in their curricula. Further, Sperandio et al. (2010) colleagues described a program that focuses on global 
citizenship education, providing students with the tools they need to think consciously about their obligations and perspectives, such as information and experiences. They discussed the Global Citizenship Program (GCP), which engaged students through practical and experiential learning, such as studying abroad and exchanging faculties. The GCP offers students the necessary tools to think critically about their responsibilities and perspectives as global citizens, such as knowledge and experiences. Moreover, Moizumi investigated the understandings and academic methods of two elementary-intermediate teachers in global citizenship education in classroom environments in Ontario and British Columbia. His investigation revealed opposing portrayals of global citizenship education that emphasize specific topics and activities found in the rules for literature and curricula (Moizumi, 2010).

Guo conducted a three-year study that explored the experiences of teacher candidates in learning to teach global citizenship, the improvements in their ideas of education for global citizenship, and the difficulties and successes they faced in education. His study demonstrates the different opportunities and challenges that teachers face in learning to educate for global citizenship and indicates the need to incorporate global citizenship education into a whole approach in teacher education programs (Guo, 2014). Also, Pashby presented a critical framework applied to findings from a critical discourse analysis of Alberta's curriculum and lesson plans, testing the assumption that Canada was ideal for global citizenship education. The study relied on a context that offers a criticism of modernity to identify inside demands for new twenty-first-century approaches to educating citizens. The main finding was that while the Alberta curriculum reflects the powerful ability for promoting a critical approach, a conflagration of different versions of liberalism sometimes leads to a false sense of multiple perspectives (Pashby, 2015).

Truong-White and McLean explored how digital storytelling provides the ability to promote transformative global citizenship education (TGCE) through the bridges to the understanding case study program that links middle and high school students internationally using digital storytelling. Drawing on a TGCE model, the researchers used multimodal critical discourse analysis to test the curriculum and multimedia tales. This study's outcomes showed that interactive storytelling had strengthened student interaction with non-mainstream viewpoints and self-reflection when integrated into the curriculum (Truong-White and McLean, 2015). In the same year, Pasha attempted to understand the importance of the philosophy of global citizenship in Pakistan. He explored, in particular, the understanding of students of the term 'global citizen' and their attitude towards the concept. Using a case study approach, interviews were conducted with six students under the national education system in a privately run school, in addition to five teachers who had completed training on global citizenship. His study focused on the students' strong national identity, which creates a sense of urgency when it comes to showing the country a positive side, with global citizenship being seen as a way to build a positive picture. The results express the need to reconsider global citizenship in the Pakistani context through a local redefinition of the definitions (Pasha, 2015). Rapoport presented an experimental study exploring teachers' perspectives on global citizenship and their attempts to bring elements of global citizenship into the classroom. The data were collected through interviews and observations. The study showed that teachers are confused about global citizenship ideas and their elements that ultimately make them feel insecure and uncomfortable to teach about global citizenship. At the same time, the teachers in the study actively found ways to convey their interpretations of global citizenship and concepts related to global citizenship through their subject frameworks (Rapoport, 2015).

In 2018, Kilinc and Tarman investigated whether some correlations existed between patriotism dimensions and global citizenship. For this research, the authors applied the method of correlation survey. They selected 202 preservice teachers using the basic random sampling method. They used the global citizenship Scale and the Patriotism Attitude Scale for collecting data. The findings showed a strong link between positive patriotism and social responsibility, global competence, and global civic participation (Kilinc and Tarman, 2018). In the same year, VanderDussen searched for the main foreign actors mobilizing constructs of 'global citizenship education. He conducted a comparative study of three main documents from the United Nations (UN) and the UNESCO, which emerged over the past five years to frame the content and pedagogy of global citizenship education among member states and educational stakeholders. He argued that it is vital to focus constructively on key stakeholders' beliefs, theories, and approaches that seek to provide answers to essential questions about the existence, purpose, and implementations of education for a wide range of local educational contexts, needs, and conditions (VanderDussen, 2018).

In 2019, Shankar performed a pilot project between students from a public university in Georgia and those from a university in Holland to advance global citizenship skills among students. The six-week program facilitated online meetings and cultural information exchange between the two groups, such as food, diet, and activity. Also, a required component of this program was a comparison of each other's national nutritional guidelines. The results of the 
project included reflections and presentations from the students on the skills, cultural competencies, and lessons learned from this experience (Shankar, 2019).

In 2013, Oxley and Morris illustrated eight significant global citizenship categories that they further divided into cosmopolitan and advocacy approaches (Figure 1). Cosmopolitanism was seen as a form of neo-imperial global citizenship, and support fosters action (Oxley and Morris, 2013).

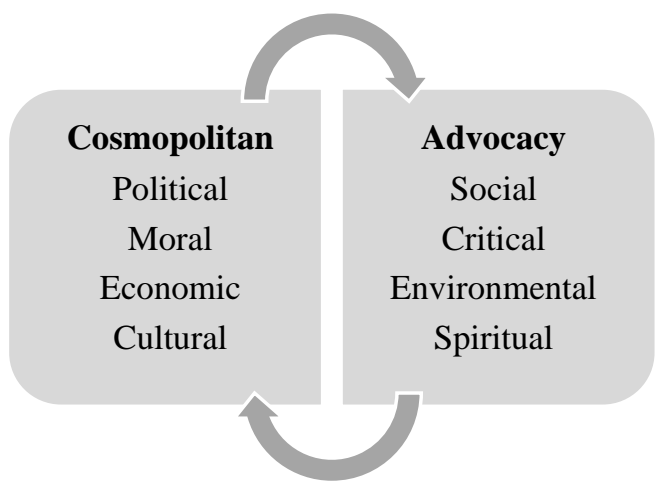

Figure 1. Categories of global citizenship

\subsection{Citizenship as a Framework}

To frame their study of academic life and the changing context of universities around the world, Rhoads and Szelényi used the concept of global citizenship. Through citizenship, they referred to a specific angle of identity, a subset of the larger concept of identity, that primarily relates to sets of rights and obligations linked to one's geographical location and global penetrations that partially help define the scale and limits of one's life across the main dimensions of social experience, namely, political, economic, and social. Individual participation as citizens represents awareness of rights and obligations across three basic social life dimensions: political (including civic), economic (including occupational), and social (including cultural). The political dimension speaks to one's participation in the civic and governmental aspects of particular organizations, social groups, and societies (the political/civic dimension can also be considered) (Rhoads and Szelényi, 2011). See Figure 2.

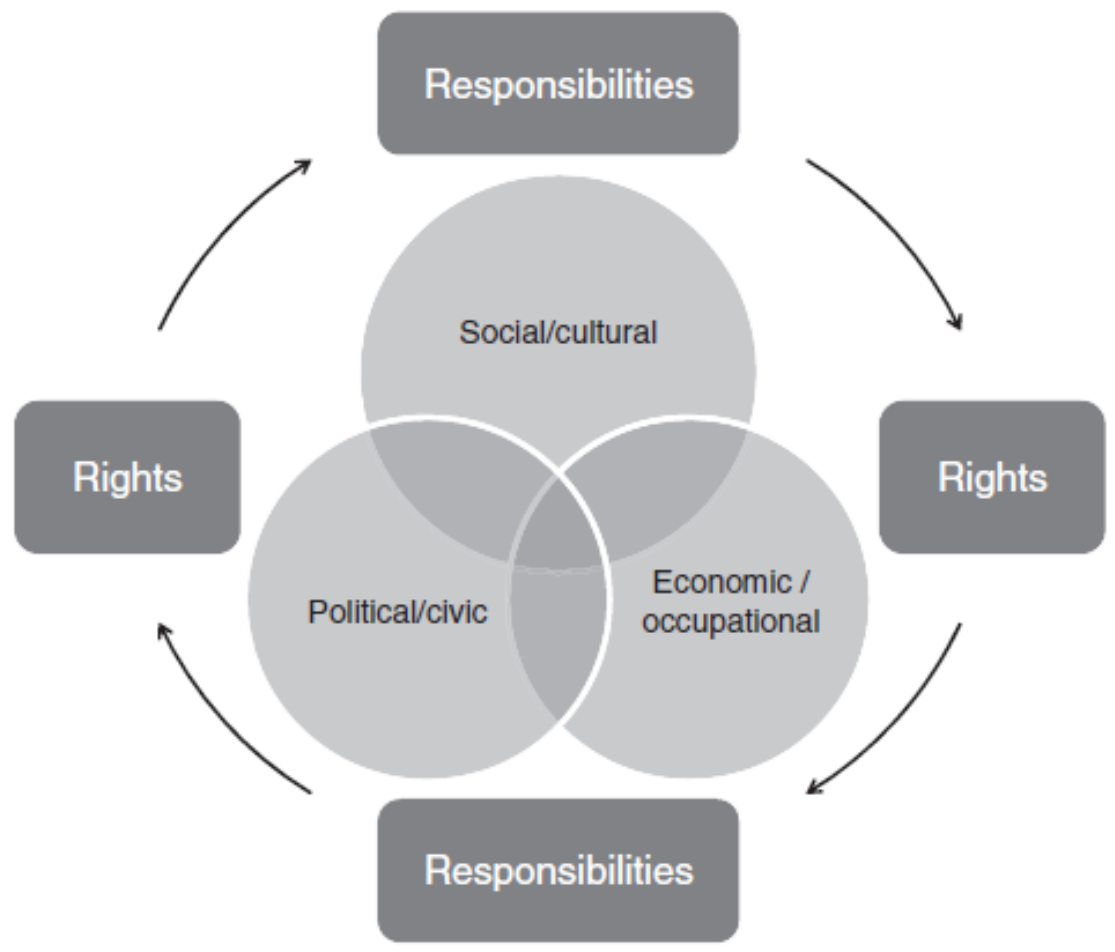

Figure 2. Conceptualizing citizenship (Rhoads and Szelényi, 2011) 
In a Canadian context, Rathbun and Lexier developed a framework that defines a global citizen. They argued that the structures of universities should adjust and change to meet their own institutional needs. They believed it was essential to enhance their capacity to build the next generation of global citizens with the position of a common language and vision that would shape the experiences of the students better; ensure that a university program evaluation is both feasible and successful and create common goals that can be shared between government and universities (Rathburn and Lexier, 2016).

\section{What benefits will global citizenship teaching bring? (Andrzejewski and Alessio, 1999)}

- Who could deny the importance of living in a safer, healthier, more peaceful, more just, and more sustainable world? In addition to these obvious long-term benefits to the world, there are immediate benefits, too.

Studying global problems and the different strategies to address them can generate a new sense of optimism and hope.

- Practicing active citizenship will add value to a program, whether through personal advancement, service learning, community organizing, or lots of other activities. Students should feel confident in communicating with various individual classes.

- Both students and teachers can see that they can make an impact, far beyond the individualistic goal of having a job, to make the world a better place. Within a prosperous world, students will understand more clearly what citizenship entails and will feel ready to make meaningful contributions to society.

\subsection{Citizenship Education}

According to Tawil, citizenship education is understood as a field of formal and informal teaching and learning for children, youth, and adults based on social, civic, and political education considered to be a significant part of citizenship development in any given context. Regardless of the path taken, education for citizenship remains a core policy area of national significance. As such, the spectrum of citizenship education is very much defined by the dynamics of governmental political structures, constellations of influence, and decision-making processes in public policy (Tawil, 2013). In 2019, Ribeiro de Brito claimed that global citizenship education could help students understand how global society is interdependent and interconnected. This education seeks to build the skills, attitudes, strategies, and global and intercultural skills that students will need to face some of the many global challenges, including climate change, global inequality, racism, migration, and poverty (Ribeiro de Brito, 2019).

Global citizenship education aims to empower learners to anticipate and assume active roles in shaping an extra peaceful, comprehensive and tolerant world (UNESCO, 2016).

Global citizenship education is intended to be transformative, developing the awareness, skills, values, and attitudes that learners need to contribute to a more sustainable, just, and peaceful world (UNESCO, 2015). This education takes a multifaceted approach, employing concepts and methodologies already applied in other areas, including human rights education, peace education, education for continuous development, and education for international understanding (UNESCO, 2014). Also, global citizenship education can be delivered as an essential part of an established field (e.g., civics or citizenship education, social studies, social/environmental studies, health education, etc.) or as a separate subject field. The former strategy, mainstreaming, is frequent (UNESCO, 2013). Fettes argued that citizenship helps young people learn about their rights and obligations, understand how society works, and develop social and political awareness. Via citizenship education, young people are allowed to act on issues of interest to themselves and play an active role in the political process, thus making society more successful (Fettes, 2007).

The promotion of global citizenship education has become an objective of educational systems in various parts of the world (Damiani, 2018). Williams (2020) indicated that Ikeda's philosophy of value-creating education in Africa addresses global citizenship as beauty, gain and good, wisdom, compassion, and courage for humanity's betterment. He said that value-creating education could inspire youth to identify and counteract the root causes of violence, poverty, discrimination, and hopelessness in their lives, homes, schools, and communities, through the creative commitment to dialogue to facilitate the transformation from a culture of violence to a culture of peace. All those are considered as an outcome of education for global citizenship.

Buchanan, Burridge, and Chodkiewicz (2018) said teaching students about global citizenship remains a critical challenge for schools and communities in Australia. There is an urgent need to help maintain support for global citizenship education. According to Education Services Australia (2011), global citizenship is about "knowing that we are all citizens of the one globe and behaving in a way that demonstrates a respect for that globe and all people on it." Within Australian schools, policies and programs address several important ways of maintaining global citizenship education. They include considering relevant pedagogies, using an existing Global Education framework, 
curriculum opportunities, relevant teacher education programs and quality educational resources, and partnerships with Non-Governmental Organizations (NGOs). Together, these initiatives can assist in maintaining support for a more meaningful global citizenship education in the face of the many challenges of the current educational context.

Hong (2020) believed that global citizenship education could raise student awareness and help to be actively engaged in defending social justice, equity, and sustainable development at both local and global levels. To achieve this in Chinese schools, competency-based education teaching methods must be utilized to underpin global citizenship education. Furthermore, Truong-White and McLean's (2015) study focused on the transformative global citizenship education theme. It showed the benefit of utilizing such technology-based initiatives could support a transformative approach to global citizenship education. Using online technologies can help students engage in citizenship activities such as discussing global problems, planning community service activities, seeking volunteer opportunities, writing blogs about a political issue, and forwarding political videos to their social networks.

Hayden, McIntosh, Sandoval-Hernández, and Thompson (2020) examined the possibility of changing student perceptions through an international curriculum. They examined the key elements related to a global citizenship education course. This course required students to engage in each of three strands and combine two or more strands in an extended activity known as the Creativity, Activity, and Service (CAS) project. This course was offered in the International Baccalaureate Diploma Programme (IBDP) as a pre-university program. Data were collected through online surveys returned by current IBDP students in schools located across 89 countries and IBDP alumni worldwide. The results showed that most respondents perceived CAS to have had a positive impact, particularly for developing individual skill sets. Respondents agreed that participating in CAS broadens their perspectives, but they reported little change in their behavior or worldview as a result.

Damiani (2018) showed the possibility of introducing global citizenship education into classroom practices. The guide for schools, A Curriculum for Global Citizenship, focused on some of the knowledge and understanding aspects identified by British NGO Oxfam, i.e., social justice and equity; diversity; globalization and interdependence. Pre-/post tests were administered at the beginning and the end of the Learning Unit (LU). It was based on the Learning Objectives (Los), structured in an assessment plan. The study results showed that the effective implementation of global citizenship education does need to involve all areas of the curriculum and school ethos and structure, extra-curricular activities, and needs to foster (local and global) community engagement and engage students in actions for change.

French's (2020) study explored how global citizenship education was conceptualized in the Province of Trento in northern Italy. This province had adopted the concept of global citizenship education and initiated policy changes in 2015 to integrate it within the curricula. The primary data-gathering method was intensive interviews with provincial decision-makers, key informants, and teachers using a grounded theory approach. This study's findings confirmed that it was very challenging for critical versions of global citizenship education that pursue subjectification to move beyond experimentation by individual educators and teachers. Their perspective is rooted in moral cosmopolitanism and a socialization approach aimed at fostering a good global citizen. The teachers merged different agendas: the economic (preparing young people for the global economy), the moral (helping others), and the cultural (fostering tolerance).

After the United Nations Secretary-General's Global Education First Initiative (GEFI) was launched in September 2012, Navarro-Leal and Salinas-Escandón (2018) identified the demand of a university in Mexico for internationalization and coping with demands to educate for global citizenship. This paper reports an experience of training teachers to promote these aspects in a Mexican university. Teachers were trained to promote internationalization and the main principles of global citizenship education. Their answers to a questionnaire specially designed for this purpose were compared with the answers of a group of teachers from the same university who had not been trained in global education. The results showed a significant difference between the two sets of answers in favor of trained teachers.

Muhammad and Brett (2017) studied challenges in Pakistan facing teaching citizenship in schools. The results showed that most teachers reported that they had been teaching only the textbooks' content on cultural diversity to remain within the curricular boundaries. There was less discussion of global identity themes in the Pakistan school textbook. Teachers argued that they could not do anything to compensate for the relative lack of representation of cultural groups because they had to follow the topics in the textbooks.

Dorio (2016) examined student perceptions of citizenship education in Egypt; he found that participants viewed peace education as a cornerstone of citizenship education. They stated that peace education should be taught in earlier levels of schooling and later on integrated into various fields within the university. Additionally, participants 
incorporated principles of empathy, ethics, and social responsibility into their peace education. Also, good humans were associated with the mission of the university. A few participants discussed ideas of citizenship education being related to creating what they would describe as global citizens. They felt that the concept of global citizenship and global citizenship education must be contextualized and grounded within an Egyptian framework. Global citizenship education specifically creates awareness and addresses the region's dilemmas, including peace and stability, extremism, and other issues.

\section{Study Objectives and Questions}

The objectives of this study were to:

- Investigate student perceptions toward global citizenship's knowledge, skills, and values at Sultan Qaboos University (SQU);

- Investigate the significant differences among student level of perception toward global citizenship related to gender, colleges, attending Global Citizenship Course (GCC), and accommodation in three domains: cognitive, socio-emotional, and behavioral domains; and

- State factors that help teachers and course designers in improving and developing course content about global citizenship.

This study answers the following questions:

1. What is the extent of student perceptions toward global citizenship's knowledge, skills, and values in the Sultanate of Oman?

2. Are there any statistically significant differences at $(\alpha=0.05)$ between the mean of students' perceptions toward global citizenship's cognitive domain according to the gender, colleges, and attending GCC?

3. Are there any statistically significant differences at $(\alpha=0.05)$ between the mean of students' perceptions toward global citizenship's socio-emotional domain according to the gender, colleges, and attending GCC?

4. Are there any statistically significant differences at $(\alpha=0.05)$ between the mean of students' perceptions toward global citizenship's behavioral domain according to the gender, colleges, and attending GCC?

5. Are there any statistically significant differences at $(\alpha=0.05)$ between the mean of students' perceptions toward global citizenship's accommodation types?

\section{Methodology}

\subsection{Research Design}

This research used a descriptive-comparative approach analyzing students' points of view toward the global citizenship concept. The data were collected from two groups of bachelor's students, those who took a GCC and those who did not. This research was conducted at SQU in the Spring and Fall of 2019. This course is offered as an elective course at the university level with two credit hours. The total population of those students taking the course was 180 students, and 174 students participated in the study. A sample of 119 students was randomly collected from those who did not study GCC in the Fall semester of 2019.

\subsection{Brief Description of the GCC at $S Q U$}

This course is considered an elective course at the university level and is offered for all colleges at the bachelor's level. The course is built around the concept of global citizenship and its principles and characteristics. The course includes many values, including peace, tolerance, accepting others, human rights, justice, and international cohesion. The course aims to develop student understanding of the role of international organizations in creating policies toward disseminating global citizenship in general and specifically in the Sultanate of Oman. This includes stability, security, coexistence, and rejecting any type of extremism. In achieving the course's objectives, students must role-play, design posters, and make a digital story of well-known local and international leaders who defend against discrimination among people around the world with justice and fairness. In addition, the course examines challenges facing youths in the dissemination of the concept of global citizenship.

\subsection{Study Sample}

The study sample included 299 students, 122 males, and 177 females. Also, the sample included 136 from the College of Science and 163 from the College of Humanities. A description of the study sample is shown in Table 1. 
Table 1. Study sample

\begin{tabular}{llll}
\hline Variables & Type & Number & $\%$ \\
\hline Gender & Male & 120 & $41.0 \%$ \\
Colleges & Female & 173 & $59.0 \%$ \\
& Science & 131 & $44.7 \%$ \\
Study GCC & Humanities & 162 & $55.3 \%$ \\
& Yes & 174 & $59.4 \%$ \\
Accommodation* & No & 119 & $40.6 \%$ \\
& On-campus & 84 & $48.0 \%$ \\
& With family & 41 & $23.0 \%$ \\
& Single & 50 & $29.0 \%$ \\
& Total & 293 & $100 \%$ \\
\hline
\end{tabular}

* those who studied GCC

\subsection{Questionnaire Validity and Reliability}

The researcher developed a survey instrument based on an extensive literature review (Karlberg, 2008; Carter, 2013; UNESCO, 2015; Hunt, 2017;). The researchers developed a list the represented the factors mentioned in UNESCO's documents about global citizenship education (2015). The core conceptual framework of the study dimensions of global citizenship education is shown in Figure 3. The cognitive domain aimed to show how students would be able to acquire knowledge, understanding, and critical thinking about global, regional, national, and local issues and the interconnectedness and interdependency of different countries and populations. While socio-emotional includes how a learner can have a sense of belonging to common humanity, sharing values and responsibilities, empathy, solidarity, and respect for differences and diversity. Finally, the behavioral domain is addressed to help students act effectively and responsibly at local, national, and global levels for a more peaceful and sustainable world (UNESCO, 2015).

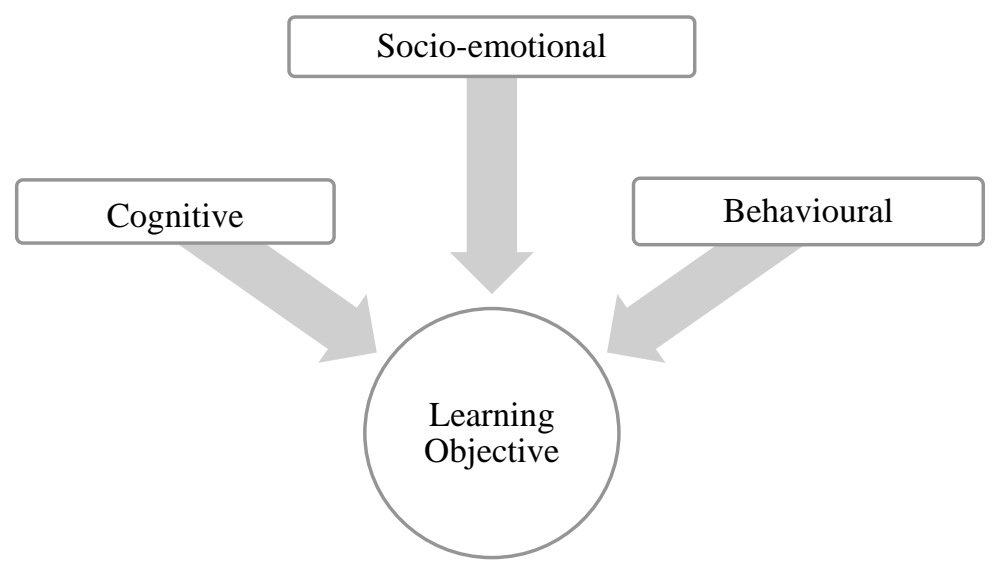

Figure 3. The core conceptual dimensions of global citizenship education

The tool's final version included 47 items covering three major core conceptual dimensions of global citizenship education: cognitive, socio-emotional, and behavioral CSeB. Each respondent rated the extent of agreement with each statement on global citizenship on a Likert-type scale with possible responses ranging from 1 to 5 , with $1=$ very low, 2 =low, 3 =average, 4 =high, and 5 =very high.

Additionally, the tool included four demographic variables the solicited information related to the respondents. The information included gender, colleges, accommodation, and studying GCC.

To determine the questionnaire's validity and reliability that included 47 items, nine experts examined the questionnaire. In addition, to assure the instrument's reliability, a random sample of 30 students was used to test the questionnaire. Cronbach's alpha was found to be 0.956 on the total items, 0.916 for cognitive, 0.872 for 
socio-emotional, and 0.929 for behavioral items. The results for Cronbach's alpha were highly statistically acceptable, as shown in Table 2.

Table 2. The results of Cronbach's alpha

\begin{tabular}{lll}
\hline Domain & Number of items & Cronbach's alpha \\
\hline Cognitive & 18 & 0.916 \\
Socio-emotional & 15 & 0.872 \\
Behavioral & 14 & 0.929 \\
Total & 47 & 0.956 \\
\hline
\end{tabular}

\subsection{Data Collection}

To collect data, an electronic questionnaire was designed. The questionnaire was distributed to the study sample via Google Forms. The link to the survey was sent to the students via email. The data were collected in the last week of the Spring semester of 2019 after finishing the GCC and in the middle of the Fall semester of 2019 for those who did not take the GCC. The GCC is offered in the Spring semester of each academic year.

\section{Results}

Because this study utilized a descriptive approach, means and standard deviations were calculated for each domain to represent a respondent's point of view regarding the GC as shown in Table 3.

Table 3. Means and standard deviation (SD) of respondents in each domain

\begin{tabular}{lll}
\hline Study domain & Mean & SD \\
\hline Cognitive & 3.24 & 0.676 \\
Socio-emotional & 4.00 & 0.568 \\
Behavioral & 3.19 & 0.823 \\
Total & 3.47 & 0.578
\end{tabular}

The statistical mean for global citizenship for all domains was 3.46. For the cognitive domain, the mean was 3.24, the mean for the socio-emotional domain was 4.00 , and the mean for the behavioral domain was 3.19. Appendix 1 shows more details about the results of the student's responses to each item in each domain.

T-tests for independent samples were analyzed to show students' perceptions toward global citizenship's cognitive domain to answer the second question. Table 4 shows the results.

Table 4. Results of t-tests of students' perceptions of global citizenship in the cognitive domain

\begin{tabular}{llllllll}
\hline Variable & Level & Number & Means & SD & $\begin{array}{l}\text { Degree } \\
\text { Freedom (df) }\end{array}$ & t-test & Significance (2-tailed) \\
\hline Study GCC & Yes & 174 & 3.53 & 0.575 & 291 & 10.406 & 0.000 \\
& No & 119 & 2.82 & 0.582 & & & \\
Gender & Male & 120 & 3.35 & 0.720 & 291 & 2.196 & 0.029 \\
& Female & 173 & 3.17 & 0.635 & & & \\
Colleges & Science & 131 & 3.19 & 0.711 & 291 & \multirow{2}{*}{1.266} & 0.206 \\
& College & & & & & & \\
& Humanities & 162 & 3.29 & 0.644 & & & \\
& College & & & & & & \\
\hline
\end{tabular}

The results in Table 4 show that statistically significant differences at $(\alpha=0.05)$ existed between the mean of students' responses for those who studied GCC and those who did not study GCC. About gender, the results in Table 4 show that males had higher perceptions of global citizenship than females for the cognitive domain.

T-tests for independent samples were analyzed to show students' perceptions toward global citizenship's socio-emotional domain to answer the third question. Table 5 shows the results. 
Table 5. Results of t-tests of students' perceptions of global citizenship in the socio-emotional domain

\begin{tabular}{llllllll}
\hline Variable & Level & Number & Means & SD & df & t-test & Significance (2-tailed) \\
\hline Study GCC & Yes & 174 & 4.09 & 0.550 & 291 & 3.024 & 0.003 \\
& No & 119 & 3.88 & 0.574 & & & \\
\multirow{2}{*}{ Gender } & Male & 120 & 4.00 & 0.621 & 291 & 0.151 & 0.880 \\
& Female & 173 & 4.01 & 0.529 & & & \\
Colleges & Science college & 131 & 4.00 & 0.543 & 291 & 0.004 & 0.997 \\
& Humanities college & 162 & 4.00 & 0.589 & & & \\
\hline
\end{tabular}

The results show in Table 5 that statistically significant differences at $(\alpha=0.05)$ are present between the mean of students' responses who studied GCC and those who did not study GCC in the socio-emotional domain. No significant differences existed between students' perceptions regarding gender and colleges.

T-tests for independent samples were analyzed to show students' perceptions toward global citizenship's behavioral domain to answer the fourth question. Table 6 shows the results.

Table 6. Results of t-tests of students' perceptions of global citizenship in the behavioral domain

\begin{tabular}{llllllll}
\hline Variable & Level & No & Means & SD & df & t-test & Significance (2-tailed) \\
\hline Study GCC & Yes & 174 & 3.37 & 0.801 & 291 & 4.74 & 0.000 \\
& No & 119 & 2.92 & 0.785 & & & \\
Gender & Male & 120 & 3.24 & .806 & 291 & 0.820 & 0.413 \\
& Female & 173 & 3.16 & .836 & & & \\
Colleges & Science college & 131 & 3.23 & 0.839 & 291 & 0.824 & 0.411 \\
& Humanities college & 162 & 3.15 & 0.811 & & & \\
\hline
\end{tabular}

The results show in Table 6 that statistically significant differences at $(\alpha=0.05)$ exist between the mean of students' responses for those who studied GCC and those who did not study GCC in the behavioral domain, while no significant differences between students' perceptions about the gender and colleges.

Question five explored the differences among students' points of view regarding their accommodations. Means and standard deviation of students' responses were analyzed (Appendix 2), and a one-way ANOVA was utilized. Table 7 shows the results

Table 7. Result of one way-ANOVA testing the study accommodation variables

\begin{tabular}{lllllll}
\hline Source & Level & Sum of Squares & df & Mean Square & F & Sig. \\
\hline Cognitive & Between Groups & 1.889 & 2 & 0.944 & 3.268 & 0.040 \\
& Within Groups & 49.717 & 172 & 0.289 & & \\
& Total & 51.606 & 174 & & & \\
Socio-emotional & Between Groups & 0.493 & 2 & 0.246 & 0.984 & 0.376 \\
& Within Groups & 43.052 & 172 & 0.250 & & \\
& Total & 43.545 & 174 & & & \\
\multirow{3}{*}{ Behavioral } & Between Groups & 0.244 & 2 & 0.122 & 0.196 & 0.822 \\
& Within Groups & 105.108 & 169 & 0.622 & & \\
& Total & 105.351 & 171 & & & \\
& Between Groups & 0.640 & 2 & 0.320 & 1.257 & 0.287 \\
& Within Groups & 43.768 & 172 & 0.254 & & \\
\hline
\end{tabular}


The results in Table 7 shows that a significant difference existed between students' points of view regarding the accommodation variable in the cognitive domain in favor of students who lived with their family compared with those who live on-campus as the post-hoc Scheffe analyses comparison in Table 8 shows.

Table 8. Scheffe post-hoc comparison results of accommodation variables in the cognitive domain

Dependent Variable $\quad$ (I) Accommodation $\quad$ (J) Accommodation $\quad$ Mean Difference (I-J) Std. Error $\quad$ Sig

\begin{tabular}{llllll}
\hline \multirow{3}{*}{ Cognitive } & on-campus & With family & $-0.259^{*}$ & 0.102 & 0.043 \\
& & Single & -0.117 & 0.096 & 0.476 \\
& with family & On-campus & $0.259^{*}$ & 0.102 & 0.043 \\
& & Single & 0.141 & 0.113 & 0.457
\end{tabular}

\section{Discussion}

This study was conducted to explore the effectiveness of GCC on students' perceptions towards global citizenship knowledge, behavior, and social values at SQU. The first question's findings showed that SQU students' perceptions toward the global citizenship study domain were generally high, with a mean of 3.47 on a 5-point Likert scale of 5 . The results showed that the socio-emotional domain had the highest mean of 4.00 of all the domains. These results can be attributed to the way students look toward global citizenship by rejecting all kinds of extremism and discrimination. They might feel more sympathetic to suffering refugees relative to human diversity and feel they are capable of independently judging people. These findings are supported by the research findings in Kalberge (2008) and Davies (2006), who stated that global citizenship as a concept builds around sharing values of identities, and social justice and rights are the most critical issues that students should understand to be an effective emotional citizen.

Concerning the second question, the results show that statistically significant differences at $\alpha=0.005$ existed in the cognitive domain in favor of those who took the GCC. This finding is supported by Sperandio and colleagues (2010), who indicated that global citizenship education program content should provide students with enough knowledge about all theories and practices. Such content will help students to think consciously about the immense responsibility they carry towards respecting others.

The results of the third question showed that the difference in GCC students' perceptions of the global citizenship social-emotional domain was significantly higher than those who did not study GCC. The result showed that GCC students are more likely to have a clear understanding of global citizenship values and can analyze problems and issues related to global citizenship. Furthermore, they have more awareness about their rights and duties as citizens. These findings are substantiated by the research findings in Pashby, 2015, and Pasha, 2015, who indicated the importance of embedded global citizenship in school curricula.

The findings of the fourth question indicated that GCC students had higher perceptions of global citizenship than students who did not study GCC. One explanation is that GCC plays a significant role in developing student skills and pro-social behavior. Thus, students who studied GCC might participate in social campaigns to raise awareness of maintaining a healthy global health environment and lead society towards tolerance and coexistence. Besides, GCC students could develop skills in voluntary work. Furthermore, students who study GCC learn more about investing their free time in conducting social activities addressing global problems and issues. Shankar (2019), who indicated the importance of exposing students to exercise global citizenship skills and manners, supported this result.

Concerning the effect of the accommodation variable on student perceptions toward global citizenship, Table 7 shows a statistical significance in the cognitive domain in favor of those who live with their families compared with those who live on campus. This result is supported by Rhoads and Szelényi (2011). They stated that individual participation as citizenship represents awareness of rights and obligations across three basic social life dimensions, including the effectiveness of social groups and culture under which he/she was raised. Furthermore, Tawil (2013) stated that individual awareness of global citizenship comes from formal and informal education. The informal type is considered a significant part of citizenship development in any social context.

According to Lagos, the role that global citizenship plays is a fuzzy one. The effort to establish a concept of global citizenship is a small step towards a better understanding of its impact and effect (Lagos, 2002). People can shoulder their global responsibility in every role they assume in their daily lives. It may be customers, candidates, workers, 
volunteers, donors, etc. Carabain and colleagues concluded that taking global responsibility is not restricted to individual citizens; organizations can also take global responsibility for their role as producers, policymakers, employers, resource users, etc. In short, we all care about global citizenship (Carabain et al., 2012).

\section{Implications}

This study investigated the effect of studying GCC on students' perceptions toward global citizenship in cognitive, social-emotional, and behavioral domains. It also examined whether student perceptions difference according to variables of gender, colleges, accommodation, and studying GCC. The study results showed the importance of developing GCC, which is considered a model course for those who work in course development.

This study's findings could be used to improve students' awareness of global social responsibilities, which will help them be more familiar with global issues and problems. This study will help the Faculty of Student Affairs at SQU develop students' global citizenship skills by conducting training, workshops, and activity for all university students addressing international issues. These activities and workshops could be effective ways to forge collaboration among students and improve their socio-emotions toward local, regional, and global citizenships issues. These research findings are interesting with implications and recommendations for best practices of global citizenship. Further studies on student perceptions, values, and practices are highly needed on a large scale and samples from other universities in the Sultanate of Oman.

Perhaps, future studies could investigate GCC's influence on student academic performance to compare the relationship between universities in the Sultanate of Oman. Because this GCC had a significant impact on student perceptions, this course can be transferred as an elective course offered to other colleges and universities in the Sultanate of Oman. In addition, this course could be developed as an online course for a public audience as a Massive Online Open Course (MOOC) type. This course could also be used as a model in developing other courses in social sciences and international studies.

\section{Conclusion}

In conclusion, studying GCC impact the students' perception of global citizenship in SQU. It develops students' skills and pro-social behavior. Offering a university-level elective course that teaches global citizenship concepts improves students' awareness and perception toward the cognitive, social-emotional, and behavioral dimensions of global citizenship. Studying GCC will impact the social-emotional dimension the most which will improve students' abilities to build positive attitudes towards global citizenship. Faculty members have a significant role in raising student knowledge and attitudes toward global citizenship. Integrating clinical practices such as introducing a virtual case in global citizenship during lectures will develop students' skills in analyzing concepts and critical thinking. The finding of this study is consistent with the 17th Sustainable Development Goals also known as Global Goals were adopted by the UN in 2015 as a universal call to action to live together with peace and prosperity.

\section{References}

Andrzejewski, J., \& Alessio, J. (1999). Education for global citizenship and social responsibility. Progressive Perspectives, 1(2), 2-17. DIO:10.1.1.524.3056

Buchanan, J., Burridge, N., \& Andrew Chodkiewicz. (2018). Maintaining global citizenship education in schools: A challenge for Australian educators and schools. Australian Journal of Teacher Education, 43(4), 51-67. https://doi.org/10.14221/ajte.2018v43n4.4

Cantón, A., \& Garcia, B. I. (2018). Global citizenship education. New Directions for Student Leadership, 160, 21-30. https://doi.org/10.1002/yd.20307

Carabain, C., Keulemans, S., van Gent, M., \& Spitz, G. (2012). Global citizenship: From public support to active participation. Amsterdam: NCDO. Retrieved February 26, 2021. from http://www.ncdo.nl/sites/default/files/NCDO\%20global\%20 citizenship.pdf

Carter, A. (2013). The political theory of global citizenship. London: Routledge. https://doi.org/10.4324/9780203183397

Damiani, V. (2018). Introducing global citizenship education into classroom practice: A study on Italian 8th Grade Students. Center for Educational Policy Studies Journal, 8(3), 165-186. DOI: https://doi.org/10.26529/cepsj.556

Davies, L. (2006). Global citizenship: abstraction or framework for action? Educational Review, 58(1), 5-25. https://doi.org/10.1080/00131910500352523 
Dorio, J. N. (2016). The struggle for "bread, freedom, and social justice": (Re) imagining citizenship(s) and university citizenship education in Egypt [Doctoral dissertation, the University of California at Los Angeles]. ProQuest Dissertations Publishing.

Education Services Australia. (2011). Defining global citizenship. Retrieved February 26, 2021, from https://www.civicsandcitizenship.edu.au/verve/_resources/S101_Defining_Global_Citizenship_ed.pdf

Fettes, T. (2007). Six approaches to Post-16 citizenship: 4. Citizenship through voluntary and community-based activities. Learning and Skills Network. London: Regent Arcade House. Retrieved February 26, 2021, from https://files.eric.ed.gov/fulltext/ED498633.pdf, http://www.lsneducation.org.uk/

Franch, S. (2020). Global citizenship education discourses in a province in Northern Italy. International Journal of Development Education and Global Learning, 12(1), 21-36. https://doi.org/10.14324/IJDEGL.12.1.03

Guo, L. (2014). Preparing teachers to educate for 21st-century global citizenship: Envisioning and enacting. Journal of Global Citizenship \& Equity Education, $4(1), \quad$ 1-23. https://journals.sfu.ca/jgcee/index.php/jgcee/article/view/121

Hayden, M., McIntosh, S., Sandoval-Hernández, A., \& Thompson, J. (2020). Global citizenship: changing student perceptions through an international curriculum. Globalization, Societies, and Education, 18(5), 589-602. https://doi.org/10.1080/14767724.2020.1816158

Hong, Y. (2020). Do the conditions in Chinese secondary school education imply a need for global citizenship education? An exploration of six secondary schools in Jiangsu. Asia Pacific Education Review, 21(3), 455-472. https://doi.org/10.1007/s12564-020-09636-y

Hunt, F. (2017). Schools for future youth evaluation report: Developing young people as active global citizens. DERC Research Report 17. London: UCL Institute of Education. Retrieved February 26, 2021, from https://discovery.ucl.ac.uk/id/eprint/10030832/9/Hunt_DERC-Report17-SFYouth-FrancesHunt.pdf

Jackson, R. (Ed.). (2003). International perspectives on citizenship, education and religious diversity. Routledge. https://doi.org/10.4324/9780203218792

Karlberg, M. (2008). Discourse, identity, and global citizenship. Journal of Social Justice, 20(3), 310-320. https://doi.org/10.1080/10402650802330139

Kilinc, E., \& Tarman, B. (2018). Global citizenship versus patriotism. Competing frameworks: Global and national in citizenship education. Charlotte, NC: IAP.

Lagos, T. G. (2002). Global citizenship-towards a definition. Retrieved February 26, 2021, from https://depts.washington.edu/gcp/pdf/globalcitizenship.pdf

Larsen, M., \& Faden, L. (2008). Supporting the growth of global citizenship educators. Brock Education Journal, 17, 91-104. https://doi.org/10.26522/brocked.v17i1.102

Marshall, T. H. (1950). Citizenship and social class. Cambridge: Cambridge University Press.

McIntosh, P. (2005). Gender perspectives on educating for global citizenship. In N. Noddings (Ed.), Educating citizens for global awareness (pp. 22-39). Teachers College Columbia University.

Moizumi, E. M. (2010). Examining two elementary-Intermediate teachers' understandings and pedagogical practices about global citizenship education [Master's thesis, The University of Toronto]. Retrieved February 26 , 2021 , from https://tspace.library.utoronto.ca/bitstream/1807/24608/1/Moizumi_Erica_M_201006_MA_thesis.pdf

Muhammad, Y., \& Brett, P. (2017). Some challenges in teaching citizenship in an Islamic context: Pakistan Studies teachers' perspectives and practices in relation to teaching about identity. Citizenship Teaching \& Learning, 12(3), 279-298. https://doi.org/10.1386/ctl.12.3.279_1

Navarro-Leal, M. A., \& Salinas-Escandón, J. M. (2018). Teachers and education for global citizenship in a Mexican university. Presented at the 16h Annual Conference of the Bulgarian Comparative Education Society, Varna, Bulgaria, June 11-15.

Noddings, N. (2005). Global citizenship: Promises and problems. In N. Noddings (Ed.) Educating citizens for global awareness (pp. 1-21). Teachers College Press.

Oxfam Development Education Programme. (2006). Education for global citizenship: A guide for schools. Oxfam GB. 
https://oxfamilibrary.openrepository.com/bitstream/handle/10546/620105/edu-global-citizenship-schools-guide091115-en.pdf?sequence=11\&isAllowed=y

Oxley, L., \& Morris, P. (2013). Global Citizenship: A typology for distinguishing its multiple conceptions. British Journal of Educational Studies, 61(3), 301-25. https://doi.org/10.1080/00071005.2013.798393

Pais, A., \& Costa, M. (2020). An ideology critique of global citizenship education. Critical Studies in Education, 61(1), 1-16. https://doi.org/10.1080/17508487.2017.1318772

Paludan, P., \& Prinds, E. (1999) Evaluation of education in citizenship and moral judgment. Copenhagen: Danish Ministry of Education.

Pasha, A. (2015). Global citizenship in Pakistan. International Journal of Development Education and Global Learning, 7(1), 33-52. https://doi.org/10.18546/IJDEGL.07.1.03

Pashby, K. (2015). Conflations, possibilities, and foreclosures: Global citizenship education in a multicultural context. Curriculum Inquiry, 45(4), 345-366. https://doi.org/10.1080/03626784.2015.1064304

Rapoport, A. (2009). A forgotten concept: Global citizenship education and state social studies standards. Journal of Social Studies Research, 33(1), 91-113. ERIC Number: EJ838655

Rapoport, A. (2015). Classroom teachers' perspectives and approaches. In M Merryfield, T. Augustine, \& J. Harshman (Eds.), Research in global citizenship education (pp. 119-136). Information Age Publishing

Rathburn, M., \& Lexier, R. (2016). Global citizenship in Canadian universities: A new framework. Journal of Global Citizenship \& Equity Education, 5(1). https://journals.sfu.ca/jgcee/index.php/jgcee/article/view/149/210

Rhoads, R. A., \& Szelényi, K. (2011). Global citizenship and the university: Advancing social life and relations in an interdependent world. Stanford University Press. https://doi.org/10.1515/9780804777803

Ribeiro de Brito, A. (2019). Global citizenship education: Empowering change with a global mindset [Master's thesis, Northwestern University]. Retrieved February 26, 2021, from https://archives.northwestu.edu/bitstream/handle/nu/50992/Ribeiro DeBrito_Andrea_icd_2019.pdf?sequence=1

Schattle, H. (2009). Global citizenship in theory and practice. In R. Lewin (Ed.), The handbook of practice and research in study abroad: Higher education and the quest for global citizenship (pp. 3-20). New York, NY: Routledge.

Shankar, P. (2019). Fostering global citizenship skills among students through an international and intercultural exchange program. Journal of the Academy of Nutrition and Dietetics, 119(9), A12. https://doi.org/10.1016/j.jand.2019.06.056

Shultz, L. (2007). Educating for global citizenship: Conflicting agendas and understandings. Alberta Journal of Educational Research, 53(3), 248-258. DOI: https://doi.org/10.11575/ajer.v53i3.55291

Sperandio, J., Grudzinski-Hall, M., \& Stewart-Gambino, H. (2010). Developing an undergraduate global citizenship program: Challenges of definition and assessment. International Journal of Teaching and Learning in Higher Education, 22(1), 12-22.

Stewart Williams, J. E. (2020). Daisaku Ikeda's philosophy of value-creating global citizenship education and Africana humanism: Africa as the continent of the 21st century. Journal of Interdisciplinary Studies in Education, 9(S1), 69-79. https://doi.org/10.32674/jise.v9iSI.1877

Tawil, S. (2013). Education for 'global citizenship': A framework for discussion. Education research and foresight-working papers. United Nations Educational, Scientific and Cultural Organization. Retrieved February 26, 2021, from http://www.unesco.org/new/fileadmin/MULTIMEDIA/HQ/ED/pdf/PaperN7EducforGlobalCitizenship.pdf

Truong-White, H., \& McLean, L. (2015). Digital storytelling for transformative global citizenship education. Canadian Journal of Education, 38(2), 1-28. https://doi.org/10.2307/canajeducrevucan.38.2.11

UNESCO. (2013). Outcome document of the technical consultation on global citizenship education: Global citizenship education-An emerging perspective. United Nations Educational, Scientific and Cultural Organization. Paris: France Retrieved February 26, 2021, from https://www.gcedclearinghouse.org/sites/default/files/ resources $\% 5 \mathrm{BENG} \% 5 \mathrm{D} \% 20$ Outcome $\% 20$ document $\% 20 \mathrm{of} \% 20$ the $\% 20$ technical $\% 20$ consultation $\% 20 \mathrm{on} \% 20 \mathrm{gl}$ obal\%20citizenship\%20education.pdf 
UNESCO. (2014). Education strategy 2014 - 2021. United Nations Educational, Scientific and Cultural Organization. Paris: France. Retrieved February 26, 2021, from https://wpf-unesco.org/eng/231288e.pdf

UNESCO. (2014). Global citizenship education: Preparing learners for the challenges of the 21st century. United Nations Educational, Scientific and Cultural Organization. Paris: France. Retrieved February 26, 2021, from https://www.unesco.at/fileadmin/Redaktion/Publikationen/Publikations-Dokumente/2014_UNESCO_GCED_Pr eparing_learners.pdf

UNESCO. (2015). Global citizenship education: Topics and learning objectives. United Nations Educational, Scientific and Cultural Organization. Paris: France. Retrieved from http://unesdoc.unesco.org/images/0023/002329/232993e.pdf.

UNESCO. (2016). Schools in action- Global citizens for sustainable developments - A guide for teachers. United Nations Educational, Scientific and Cultural Organization. Paris: France. Retrieved February 26, 2021, from http://www.unesco.org/new/fileadmin/MULTIMEDIA/FIELD/Santiago/pdf/ASPnet-teachers-2016.pdf

VanderDussen Toukan, E. (2018). Educating citizens of 'the global': Mapping textual constructs of UNESCO's global citizenship education 2012-2015. Education, Citizenship and Social Justice, 13(1), 51-64. https://doi.org/10.1177/1746197917700909

Yemini, M., \& Furstenburg, S. (2018). Students' perceptions of global citizenship at a local and an international school in Israel. Cambridge Journal of Education, 48(6), 715-733. https://doi.org/10.1080/0305764X.2017.1418835 


\section{Appendix 1}

Means and SD of students' responses for all domains

\begin{tabular}{l} 
First Domain: Cognitive \\
\hline 1. I have a clear understanding of the values of global citizenship. \\
2. I know issues related to the concept of global citizenship. \\
3. I understand what is going on around me. \\
4. I can distinguish between right and wrong practices about global citizenship. \\
5. I can analyze issues related to global citizenship. \\
6. I understand diversity in human societies. \\
7. I can distinguish between conflicting values and beliefs. \\
8. I have the skill of critical analysis of practices associated with the global citizen. \\
9. I can distinguish between types of citizenship (local, regional, international, global) \\
10. I have the skill of fact-finding for issues related to global citizenship. \\
11. I understand the problems that are going on in the world resulting from the lack of a \\
12. I have a clear understanding of international laws and adherence to them. \\
13. I realize the cultural expressions of global citizenship. \\
14. I have the skill of fact-finding and access to global citizenship from its primary sources. \\
15. I have a clear understanding of global governance structures and their problem-solving \\
16. I know international conventions and constitutions related to global citizens. \\
17. I know my rights and duties toward global citizenship. \\
18. I can be careful of deviant intellectual currents.
\end{tabular}

\section{Second Domain: Socio-emotional}

1. I can be independent of judgment.

2. I seek to reject all kinds of extremism and discrimination

Mean

3.19

$3.12 \quad 1.102$

$3.47 \quad .948$

$3.73 \quad 1.066$

$3.12 \quad 1.042$

$3.89 \quad .895$

$3.57 \quad .992$

$3.03 \quad .951$

$3.27 \quad 1.071$

$3.05 \quad .993$

$3.31 \quad 1.067$

$3.21 \quad 1.005$

$3.05 \quad 1.023$

$2.82 \quad 1.041$

$2.64 \quad 1.058$

$2.57 \quad 1.112$

$3.52 \quad 1.130$

$3.82 \quad .991$

Mean SD

$4.02 \quad .936$

$4.12 \quad 1.005$

$4.21 \quad .881$

$3.44 \quad 1.102$

4. I am interested in global environmental issues (desertification, global warming, pollution, reserves...)

5. I sympathize with issues related to refugees, displaced persons, and forcibly deported.

$4.18 \quad .998$

$3.97 \quad 1.016$

$4.41 \quad .882$

$4.60 \quad .754$

$4.23 \quad .897$

$3.90 \quad .909$

$3.40 \quad 1.078$

$3.16 \quad 1.009$

$3.77 \quad 1.094$

$4.53 \quad .836$

$4.13 \quad 1.193$

Mean SD 
1. I spread a culture of tolerance and coexistence.

2. I participate in awareness campaigns on the environment and global health.

3. I'm playing my role as a global citizen of community responsibility.

4. I do pastoral community activities for the benefit of the world.

5. I participate in donation campaigns (donations in kind, finance, and blood)

$3.49 \quad 1.152$

6. I participate in fundraising for those exposed to all kinds of calamities in the world.

7. I'm using social media to spread the culture of global citizenship.

8. I make decisions in light of my understanding of global citizenship.

9. I share constructive opinions and criticism of issues related to global citizenship.

10. I invest leisure time in development activities related to global citizenship.

11. I'm trying to spread the public good globally.

12. I lead awareness campaigns globally.

$2.49 \quad 1.225$

13. I have the skill of analyzing governance systems and organizational structures
associated with global citizenship.

$2.53 \quad 1.169$

14. I am seeking to join one of the international humanitarian organizations.

$3.22 \quad 1.352$




\section{Appendix 2}

Means and SD of students' responses for all domains according to accommodation variable (on-campus, with family, \& single)

\begin{tabular}{llllc}
\hline Domains & Course & N & Mean & SD \\
\hline \multirow{2}{*}{ Cognitive } & on-campus & 84 & 3.46 & 0.499 \\
& with family & 41 & 3.72 & 0.581 \\
Socio-emotional & single & 50 & 3.57 & 0.561 \\
& on-campus & 84 & 4.10 & 0.535 \\
& with family & 41 & 4.20 & 0.482 \\
Behavioral & single & 50 & 4.05 & 0.450 \\
& on-campus & 81 & 3.38 & 0.693 \\
Total & with family & 41 & 3.45 & 0.994 \\
& single & 50 & 3.34 & 0.743 \\
& on-campus & 84 & 3.64 & 0.462 \\
\hline
\end{tabular}

\section{Copyrights}

Copyright for this article is retained by the author(s), with first publication rights granted to the journal.

This is an open-access article distributed under the terms and conditions of the Creative Commons Attribution license (http://creativecommons.org/licenses/by/4.0/). 